Nova Southeastern University

From the SelectedWorks of Kathy L Cerminara

2020

Today's Crusades: A Therapeutic Jurisprudential Critique of Faith-Based Civil Rights in Health Care

Kathy L Cerminara

NOVA SOUTHEASTERN UNIVERSITY

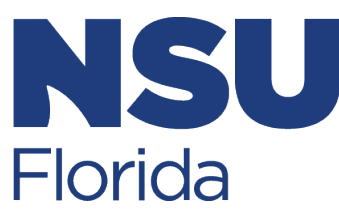

Available at: https://works.bepress.com/

kathy_cerminara/19/ 


\title{
TODAY'S CRUSADES: A THERAPEUTIC JURISPRUDENTIAL CRITIQUE OF FAITH- BASED CIVIL RIGHTS IN HEALTH CARE
}

"The ' $\mathrm{T}$ ' has become the ground zero in the culture war over LGBT rights."1

\author{
Kathy L. Cerminara*
}

\section{INTRODUCTION}

In the late 1000s, Pope Gregory VII ushered in the Crusades by announcing "the project of an armed expedition against the enemies of God." 2 Thousands of men thereafter fought in a series of wars against those of the Islamic faith, an enemy the Catholic Church demonized through propaganda. ${ }^{3}$ In other words, an important leader encouraged action against a demonized population in the name of faith. Today, an important leader, the President of the United States, acting through Executive Branch agencies, supports discrimination against transgender individuals in the name of faith with the same fervor. ${ }^{4}$ Two such attempts within health care provide opportunities for reflection and correction.

The Trump Administration has taken an anti-therapeutic approach to many provisions of health law within the purview of

* Professor of Law, Nova Southeastern University Shepard Broad College of Law. Great thanks go to Jamie Baboolal, Anabel Cordero, Professor Becka Rich, and Emily Spring. Associate Dean Brietta Clark deserves a shout-out for preventing a major faux pas, and Anton Marino deserves great credit for assistance through consciousness raising on this subject.

1 Robin Fretwell Wilson, Being Transgender in the Era of Trump: Compassion Should Pick Up Where Science Leaves Off, 8 U.C. IRVINE L. REV. 583, 587 (2018) (describing a range of laws and debates relating to the transgender population).

2 Dana C. Munro, The Western Attitude toward Islam During the Crusades, 6 SPECULUM 329, 330 (1931).

3 See id. at 329-30.

4 See Craig Klugman, Bigotry in Medicine: Legal, Yes. Ethical, No., BIoETHICs (May 8, 2019), http://www.bioethics.net/2019/05/bigotry-in-medicine-l egal-yes-ethical-no ("The administration seems threatened by people who transition and are [sic] setting up roadblocks to their fair and equal treatment in society."). 
the federal government. It has supported and encouraged legislative attempts to repeal the Affordable Care Act (ACA) time and time again, ${ }^{5}$ despite the ACA's having cleared the pathway to health care coverage (and the peace of mind that comes with it) for millions of Americans. ${ }^{6}$ It has supported denial of coverage for gender-affirming medical services to transgender individuals in the military. ${ }^{7}$ It has even cited such health care costs as a reason to ban transgender individuals from military service entirely. ${ }^{8}$

In contrast, health care professionals are charged with healing, comforting, and maintaining the dignity of their patients. ${ }^{9}$ This includes a focus on psychological health as well as physical health, even when a doctor is treating a patient with a physical problem. ${ }^{10}$ Therapeutic jurisprudence (TJ) is the equivalent in the law: an approach to making, interpreting, and applying the law that counsels legal professionals to mind the psychological effects of the legal system in operation, even if the legal issue they address does not relate to mental health law. ${ }^{11}$ Within

5 See John Tozzi, How Trump is Remaking Health Insurance Without Repealing Obamacare, INS. J. (June 17, 2019), http://www.insurancejournal.com/ news/national/2019/06/17/529589.htm (describing regulatory actions of the administration occurring after President Trump was "frustrated after attempts to repeal Obamacare fell apart in the Republican-controlled Senate").

6 See DANiEl E. DAWES, 150 Years OF ObamacARe, 239 (2016). By March 2015, approximately 11.7 million people had purchased health insurance through an Affordable Care Act (ACA) marketplace. Id.

7 See Dave Muoio, Transgender Patients: Calculating the Actual Cost, FIRST REP. MANAGED CARE (Sept. 2017), http://www.managedhealthcareconnect.com/ar ticle/transgender-patients-calculating-actual-cost.

8 See Jocelyn Samuels \& Mara Keisling, The Anti-Trans Memo Abandoning Doctors and Patients, 380 NEw EnG. J. MeD. 111, 112 (2019); Kate Thomas, Opinion, Military 'Transgender Ban' Disregards Science, Humanity, BALT. Sun (Jan. 29, 2019, 11:40 AM), http://www.baltimoresun.com/opinion/oped/bs-ed-op-0130-transgender-ban-20190129-story.html.

9 See Harvey Chochinov, Dignity and the Essence of Medicine: The A,B,C, and $D$ of Dignity Conserving Care, 334 BMJ 184, 185 (2007) (identifying "kindness, humanity, and respect" as "the core values of medical professionalism"); Samuels \& Keisling, supra note 8, at 112.

10 See Mary C. Beach et al., Do Patients Treated With Dignity Report Higher Satisfaction, Adherence, and Receipt of Preventative Care?, 3 AnNALS FAM. MED. 331, 335 (2005) (revealing an "association between treatment with dignity and receipt of optimal preventive care, consistent across all racial/ethnic groups"). See also Win Tadd et al., Dignity in Health Care: Reality or Rhetoric, 12 Reviews in Clinical Gerontology, 1, 2 (2002) (stating "that the perception of the patient as a person possessing dignity is of the utmost importance in practice").

11 Kathy L. Cerminara, Therapeutic Jurisprudence's Future in Health Law: Bringing the Patient Back into the Picture, 63 INT'L J.L. \& PsYchIATRY 56, 61 (2019) (exploring dignity as a fertile area of scholarly development in both 
health law, the laws regulating health care professionals should not stand in the way of medical goals, including the maintenance of dignity, but instead should assist in achieving them. ${ }^{12}$ Lawmakers, judges, and executive agencies should strive to honor those same goals, assisting in healing by incorporating TJ principles to ensure that the law respects the dignity of those caught up within the system's operation. ${ }^{13}$

Consistent with its overall animosity toward transgender individuals, ${ }^{14}$ the Trump Administration recently shifted a main focus of the Department of Health and Human Services (HHS) from safeguarding patient dignity to protecting health care professionals. In two different but related areas, the Administration has exercised its executive power through agency action to significantly weaken protections in the law for the transgender population. Most recently, HHS has proposed eliminating protections for transgender individuals in regulations guiding enforcement of section 1557 of the ACA, ${ }^{15}$ which was enacted to ensure that no American should have to endure discrimination on the basis of race, color, national origin, disability, age, or sex in the provision of health care. ${ }^{16}$ The HHS also has promulgated a final rule that purports to permit health care providers, without qualification, to refuse to provide many services to not only this population but also several other vulnerable groups based on religious beliefs. ${ }^{17}$

II. The Regulatory War on the Transgender Population

This Article will demonstrate that the Administration's

physician and mental health law).

$12 \mathrm{Id}$.

13 Id. See also Michael L. Perlin, "Have You Seen Dignity?”: The Story of the Development of Therapeutic Jurisprudence, 27 N.Z. U. L. REV. 1135, 1137 (stating his position that "dignity is the core of the entire therapeutic jurisprudence enterprise").

14 See Michael R. Ulrich \& Julia R. Raifman, How Religious Refusal Laws are Harming Sexual Minorities, HeALTH AFF. BlOG (June 11, 2018), http://www. healthaffairs.org/do/10.1377/hblog20180607.856152/full (describing the Administration as "systematically discontinuing sexual orientation and gender identification data collection").

1542 U.S.C. $§ 18116$ (2012).

16 Nondiscrimination in Health and Health Education Programs or Activities, 84 Fed. Reg. 27,846 (proposed June 14, 2019) (to be codified at 42 C.F.R. pt. $438,440,460$ \& 45 C.F.R. pt. $86,92,147,155,156)$.

1745 C.F.R. pt. 88 (2019). 
animosity toward medical care for transgender individuals is psychologically anti-therapeutic and reduces the quality of medical care that population receives, resulting in a "public health crisis."18 First, the Article will review the Administration's relevant rulemaking activities and the controversy surrounding them, focusing on the discrimination that the regulations encourage against transgender individuals. Second, it will explore the psychological effects (and some of the relevant physical health considerations) of such discrimination on the people affected. Finally, it will apply TJ principles to demonstrate how accounting for the psychological impact of discrimination by incorporating medical ethics into conscience clause enforcement would better serve individuals' and the public's health. These Crusades must stop.

"Transgender is an umbrella term used to describe people with a wide range of gender identities which are different from their sex assigned at birth." 19 Identifying a person as being transgender, or "trans," is legally difficult in the United States because this country, unlike a wide range of others, traditionally has recognized only two genders, male and female. ${ }^{20}$ Many in the United States have mistreated those questioning their gender identity. ${ }^{21}$

The Trump Administration has demonstrated animosity toward the transgender population in two recent regulatory activities. In May 2019, it released for comment a proposed regulation that would eliminate protection against discrimination based on transgender individuals in health care. Earlier that month, it finalized regulations clearing a path through which health care professionals, staff, and entities may discriminate against transgender individuals in the name of faith. Both of

\footnotetext{
18 See Wilson, supra note 1 , at 587.

19 Rebekah Thomas et al., Ensuring an Inclusive Global Health Agenda for Transgender People, 95 Bulletin of the World Health ORGanization [WHO] 154, 154 (2017), https://www.who.int/bulletin/volumes/95/2/16-183913.pdf; Wilson, supra note 1, at 583 n.2 ("an umbrella term [used] to refer to individuals whose gender identity is different from their sex at birth"); id. at 595 ("an umbrella term, encompassing individuals who identify with a gender that is different from their sex at birth").

20 Thomas et al., supra note 19, at 154 (listing a number of countries recognizing a third gender in both law and culture).

21 See Lesbian, Gay, Bisexual, and Transgender Health, Healthy People 2020, http://www.healthypeople.gov/2020/topics-objectives/topic/lesbian-gay-bise xual-and-transgender-health (describing discrimination and violence against the LGBT population) (last visited Jan. 29, 2020).
} 
these are related to the Administration's creation of a new Conscience and Religious Freedom Division within the Department of Health and Human Services, the leader of the Administration's crusades against access to health care for the trans population. ${ }^{22}$

\section{A. ACA's Section 1557's Prohibition of Discrimination Against Transgender Individuals}

Among its many groundbreaking achievements, the ACA took a giant step toward health equity by incorporating a provision prohibiting exclusion from, benefit denial by, or discrimination within "any health program or activity" on the basis of race, color, national origin, sex, age, or disability. ${ }^{23}$ Although race, color, national origin, age, and disability discrimination had been prohibited before the ACA, "no federal law barred sex discrimination across federally funded health care" before its passage. ${ }^{24}$ In Section 1557, the ACA "strengthen[ed] and expand[ed] protections... for population groups that have long endured discrimination in access to health care . . by prohibiting their exclusion from participating in, being denied the benefits of, or being subjected to discrimination under any health program or activity" receiving any federal financial assistance. ${ }^{25}$ Consistent with previous judicial interpretations of the term "sex" within the relevant law, HHS in 2016 regulatorily defined the word as encompassing "sex stereotyping, pregnancy (and termination of pregnancy), and gender identity." 26

President Trump was elected that same year, taking office in 2017. Between his election and his inauguration, a judge in

22 See discussion infra Section III.B. for the history of that division.

2342 U.S.C. $\S 18116$ (a) (2012) (prohibiting discrimination on the basis of grounds "prohibited under title VI of the Civil Rights Act of 1964" (race), "title IX of the Education Amendments of 1972" (gender), "the Age Discrimination Act of 1975" (age), "or section 5034 of the Rehabilitation Act of 1973" (disability)).

24 Elizabeth Sepper \& Jessica L. Roberts, Sex, Religion, and Politics, or the Future of Healthcare Antidiscrimination Law, 19 MARQ. BENEFITS \& Soc. WELFARE L. REV. 217, 223 (2018). States and localities, of course, are free to prohibit such discrimination, and some have. See generally Maps of State Laws By Issue, HumAN RIGHTS CAMPAIGN, https://www.hrc.org/state-maps (last visited Feb. 24, 2020) (including one map of jurisdictions which prevent discrimination in transgender healthcare).

25 See DAWES, supra note 6, at 222-23 (2016).

26 Sepper \& Roberts, supra note 24, at 219. See also Nondiscrimination in Health Programs and Activities, 84 Fed. Reg. 31,375, 31,387. 
Texas issued a nationwide injunction suspending enforcement of the section 1557 regulations to the extent they prohibited discrimination based upon "sex stereotyping, pregnancy (and termination of pregnancy), and gender identity." 27 Once the Trump Administration was in power, its Department of Justice (DOJ) sought a stay of that litigation, stating that HHS's Office of Civil Rights (OCR) would revise the regulation to reflect the court's ruling. ${ }^{28}$ HHS has not enforced the 2016 regulations, instead proposing new regulations that permit discrimination based on termination of pregnancy and gender identity. ${ }^{29}$

The rewrite by the Trump Administration's HHS was "part of the [A]dministration's overarching executive effort. HHS Secretary Tom Price and President Donald Trump have vowed to use administrative power to mitigate the health law's policy changes, specifically those that created 'regulatory or economic burdens' or that don't match up with the current White House agenda." ${ }_{0}$ Professor Sara Rosenbaum, a health care and policy scholar, has characterized that agenda as "not tak[ing] civil rights seriously." ${ }_{11}$ Oddly enough, in another set of regulations discussed next, the Administration vigorously supports a civil right it has identified within the Free Exercise Clause of the U.S. Constitution. Indeed, as this Article will demonstrate, the Administration appropriates the language of civil rights in the name of prejudice, resulting in harm to both individuals and the public.

27 See Katie Keith, DOJ Comes out Against 1557 Rule; New Proposed Rule May be Coming soon, HeAlth AFF. BloG (Apr. 10, 2019), http://www.health affairs.org/do/10.1377/hblog20190410.677914/full.

28 See Id. That ruling, issued in December 2018, occurred before the Trump administration released a final rule in May 2019. The administration has administratively delayed enforcement of the final rule until November 22, 2019. Conscience Rule Effective Date Moved to Nov. 22, 2019, U.S. DEP'T OF HEALTH \& HuM. SERVICES, https://www.hhs.gov/conscience/conscience-rule-effective-datemoved/index.html (last visited Jan. 30, 2020).

29 Nondiscrimination in Health and Health Education Programs or Activities, 84 Fed. Reg. 27,846, 27,891-95.

30 Shefali Luthra, Trump Puts Transgender Health Care in the Crosshairs, DAILY BEAST (July 13, 2017, 12:37 AM), http://www.thedailybeast.com/trumpputs-transgender-health-care-in-the-crosshairs.

31 Id. 


\section{B. Conscience Clauses as Anti-Discrimination and Civil Rights Statutes}

The case in Texas in which a judge enjoined the operation of the section 1557 regulations arose out of the concerns of some faith-based health care organizations claiming rights grounded in several provisions of the Constitution and the United State Code to refuse to serve patients whose lifestyle their religions condemned. ${ }^{32}$ The refusal to participate in certain procedures or to facilitate certain treatments based on morals, religion, or conscience is common. ${ }^{33}$ Several federal and state statutes and non-controversial principles of medical ethics have preserved and sought to respect conscientious objections within health care for many years. ${ }^{34}$

Traditionally, however, such objections arise when health care professionals raise moral or religious objections to participating in abortion, other reproductive-related procedures, or sterilization. These types of objections-to particular procedures-have affected the transgender community because gender-affirming surgery sterilizes the person undergoing it, constituting a basis for objection among people of some religions. ${ }^{35}$ Medical ethics supports physicians' "hav[ing]

32 First Amended Complaint at 3, Franciscan Alliance, Inc. v. Burwell, No. 7:16-cv-00108-O (N.D. Tex. 2016). "The Regulation not only forces healthcare professionals to violate their medical judgment, it also forces them to violate their deeply held religious beliefs." First Amended Complaint at 3, Franciscan, No. 7:16-cv-00108-O.

33 See Farr A. Curlin et al., Religion, Conscience, and Controversial Clinical Practices, 356 New ENG. J. MED 593, 597 (2007) ("The proportion of physicians who object to certain treatments is substantial").

34 See 45 C.F.R. pt. 88 (2019); Ronit Y. Stahl \& Ezekiel J. Emanuel, Physicians, Not Conscripts - Conscientious Objection in Health Care, 376 NEW ENG. J. MED. 1380, 1384 (2017) (Stahl and Emanuel have described a "proliferation of conscientious objection legislation in health care" since the 1970s.); Klugman, supra note 4 (Craig Klugman has noted that, as of May 2019, 46 states "permit[ted] conscience objection for performing abortions."); H314A2018: Health Care Providers Right of Conscience, Am. OsTeOPATHIC Ass'N: AOA POL'Y SEARCH (Aug. 24, 2018), http://osteopathic.org/about/leadership/policy-sear ch/?aoatextsearchinline=H314-A\%2F18; Physician Exercise of Conscience: Code of Medical Ethics Opinion 1.1.7, AMA, http://www.ama-assn.org/deliveringcare/ethics/physician-exercise-conscience (last visited Jan. 29, 2020).

35 See, e.g., Victoria Pelham, Women's Health Advocates Push back on New HHS Division, Bloomberg L. NEWs (July 24, 2018, 3:06 PM), http://news.bloom 
considerable latitude to practice in accord with well-considered, deeply held beliefs that are central to their self-identities," as long as they still "provide care in emergencies, honor patients' informed decisions to refuse life-sustaining treatment, and respect basic civil liberties and not discriminate against individuals in deciding whether to enter into a professional relationship with a new patient." 36 The ethical guidelines illustrate "a compromise between conscience and care." 37

The Trump Administration's conscience clause regulations go further, sanctioning broader refusals to treat. Some faiths view a person's acknowledgement of non-binary gender itself as "unnatural" and sinful. ${ }^{38}$ A 2017 nationwide survey indicated that twenty-nine percent of transgender respondents who had visited a doctor within the last year had been refused care because of their actual or perceived gender identity; these were refusals to see patients entirely, not refusals to provide services related to gender affirmation. ${ }^{39}$ Human Rights Watch has reported refusals of "basic health care" to transgender individuals in Mississippi and has quoted a social worker recounting a refusal of psychiatric care to a transgender child as saying, "[i]t

berglaw.com/health-law-and-business/womens-health-advocates-push-back-onnew-hhs-division (explaining that "[s]ome Catholics view gender transition care as a form of sterilization.”).

36 AMA, supra note 34. See also Prospective Patients: Code of Medical Ethics Opinion 1.1.2, AMA, http://www.ama-assn.org/delivering-care/ethics/prospective -patients (last visited Jan. 29, 2020).

37 Elizabeth Sepper, Toppling the Ethical Balance - Health Care Refusal and the Trump Administration, 381 NEW ENG. J. MED. 896, 896 (2019).

38 See, e.g., Moshoula Capous-Desyllas \& Cecillia Barron, Identifying and Navigating Social and Institutional Challenges of Transgender Children and Families, 34 ChILd AdOLEscent Soc. WoRK J. 527, 539 (2017) (describing challenges for family with a transgender child stemming from religious beliefs "wherein being transgender is deemed as 'unnatural' according to God and therefore a 'sin."'). See also id. at 536 (describing a religious family member as likely saying transgenderism was "against God's nature" and a friend as praying that a transgender child would "stop sinning.").

39 Shabab Ahmed Mirza \& Caitlin Rooney, Discrimination Prevents LGBTQ People From Accessing Health Care, CTR. FOR AM. Progress (Jan. 18, 2018, 9:00 AM), http://www.americanprogress.org/issues/lgbt/news/2018/01/18/445130/discr imination-prevents-lgbtq-people-accessing-health-care. See Keren Landman, Doctors Refuse to Treat Trans Patients More Often Than You Think, VICE (Jan. 29, 2018, 6:53 PM), http://www.vice.com/en_us/article/j5vwgg/doctors-refuse-totreat-trans-patients-more-often-than-you-think ("These findings [from the survey conducted by the Center for American Progress] are similar to those in the 2015 US Transgender Survey, in which 23 percent of respondents reported abstaining from necessary healthcare over the past year due to fear of being mistreated by providers."). 
was the doctor there... once he found out the child was a trans child he said they would not be able to accommodate them for the psych evaluation. The family was told they don't provide services to trans clients." 40 Far beyond objecting to specific procedures, these health care professionals have refused to care for transgender persons at all. ${ }^{41}$

The first definition within the new conscience clause regulations provides an example. In several places, the new regulations instruct individuals and entities not to discriminate against others (whether health care professionals or not) refusing to perform or "assist in the performance of" activities to which they object based on religious beliefs or moral convictions. ${ }^{42}$ The regulation defines "assist in the performance" as follows:

Assist in the performance means to take an action that has a specific, reasonable, and articulable connection to furthering a procedure or a part of a health service program or research activity undertaken by or with another person or entity. This may include counselling, referral, training, or otherwise making arrangements for the procedure or a part of a health service program or research activity, depending on whether aid is provided by such actions. ${ }^{43}$

Thus, a refusal to refer to another provider is protected. ${ }^{44}$ So is

40 Ryan Thoreson, Human Rights Watch, "You Don’t Want Second Best": ANTI-LGBT DiSCRIMINATION IN US HEALTH CARE 22 (2018), http://www.hrw.org/r eport/2018/07/23/you-dont-want-second-best/anti-lgbt-discrimination-us-healthcare.

41 See, e.g., Movement AdVAncement Project \& NAT'L CTR. FoR Transgender Equality, Religious Refusals in Health Care: A Prescription FOR DiSASTER 5 (2018), http://www.lgbtmap.org/Religious-Refusals-Health-CareReport (describing a pediatrician legally able to "turn away an infant for a newborn checkup because the baby had two mothers" and doctors "[r]efusing to treat drug addiction if providers think drug use is a moral failing. Religious refusal laws allow healthcare providers to deny care based on the personal objections of staff."). See also Kami Kosenko et al., Transgender Patients Perceptions of Stigma in Health Care Contexts, 51 MED. CARE 819, 821 (2013) (Although the study did not investigate providers' motives for their actions, the study did find that "[o]ne in [five] problematic interactions reported by participants involved health professionals refusing to care for transgender patients. This included the providers' denial of desired medical treatments (e.g., hormone treatments or referrals for gender reassignment) and their refusal to meet or make appointments with transgender patients.") (emphasis added).

42 See 45 C.F.R. $§ 88.3$ (2019).

4345 C.F.R. $\S 88.2$.

44 Protecting Statutory Conscience Rights in Health Care; Delegations of Authority, 84 Fed. Reg. 23,170, 23,188 (May 21, 2018) (to be codified at 45 
an ambulance driver's refusal to drive a patient somewhere in order to obtain an abortion whatever the situation (i.e., whether or not the mother's life was in danger). ${ }^{45}$ So is a refusal to provide a referral for treatment for gender dysphoria ${ }^{46}$ or genderaffirming treatments viewed as sterilizations. ${ }^{47}$

HHS has advised that "where the scope of laws that are the subject of this regulation is limited to certain enumerated procedures, the final rule makes clear that OCR will pursue enforcement of those laws only with respect to the enumerated procedures," 48 but not all laws are so limited. The Church Amendment, enacted to protect the rights of individuals and entities objecting to sterilizations and abortions, provides an example. ${ }^{49}$ In one provision, the statute and the regulation tracking it limit religious or moral objections by providing that entities receiving HHS-administered grants or contracts for biomedical or behavioral research may not discriminate against a

physician or other health care personnel ... because he refused to perform or assist in the performance of any such service or activity on the grounds that his performance or assistance in the performance of such service or activity would be contrary to his religious beliefs or moral convictions, or because of his religious beliefs or moral convictions respecting any such service or activity. ${ }^{50}$

In contrast, the next provision of the Church Amendments and the regulation tracking it prohibit health service programs or

C.F.R. pt. 88); see also Lawrence O. Gostin, The "Conscience" Rule: How Will It Affect Patients' Access to Services?, 321 JAMA 2152, 2153 (2019) (stating that "the rule not only allows health workers to deny services, but also to limit information on where patients could receive the service").

45 Protecting Statutory Conscience Rights in Health Care; Delegations of Authority, 84 Fed. Reg. 23,170, 23,188. See also Gostin, supra note 44, at 2153 (stating that "rule's expansive definition of covered entities could... extend to ... an ambulance driver transporting a woman for an emergency abortion").

46 Gostin, supra note 44, at 2153 (listing this as one of the potential effects of the rule along with "discourag[ing] treatment-seeking behavior and caus[ing] stigma").

47 See Katie Keith, Trump Administration Finalizes Broad Religious and Moral Exemptions for Health Care Workers, HeAlth AfF. BlOG (May 3, 2019), ht tp://www.healthaffairs.org/do/10.1377/hblog20190503.960127/full/ (noting that OCR provided "no direct answer" to whether such a refusal would be protected, "saying that it will evaluate complaints on a case-by-case basis").

48 Protecting Statutory Conscience Rights in Health Care; Delegations of Authority, 84 Fed. Reg. 23,170, 23,182.

49 See 42 U.S.C. § 300a-7 (2009).

5042 U.S.C. $\S 300 a-7(c)(2) ; 45$ C.F.R. $\S 88.3(a)(2)(v)$ (emphasis added). 
activities funded wholly or partially under a program administered by HHS from requiring an individual "to perform or assist in the performance of any part of [that] health service program or research activity ... if his performance or assistance in the performance of such part of such program or activity would be contrary to his religious beliefs or moral convictions." 51 "Under this provision, an individual cannot be required to perform or assistance in the performance of any part of a health service program or research activity if doing so would be contrary to their religious beliefs or moral convictions." ${ }_{2}$

\section{THE RESULTING HARM TO TRANSGENDER INDIVIDUALS}

Both the proposed 1557 regulations and the final conscience clause regulations harm transgender persons. Regulatorily eliminating gender identity as a prohibited basis for discrimination in health care will permit well-known

5142 U.S.C. $\S 300 a-7(d) ; 45$ C.F.R. $§ 88.3(a)(2)(v i)$ (emphasis added).

52 See Keith, supra note 47. Although tracking the text, this is an extremely broad interpretation of the Church Amendment itself, given its focus on sterilization and abortion. See Letter from James L. Madara, Exec. Vice President, CEO, American Medical Association, to Alex M. Azar, Secretary, U.S. Dep't of Health \& Human Servs. 2 (Mar. 27, 2018) (quoting Senator Church during debate on the amendment as stating that the objections had to be related to a procedure that was objectionable), https://searchlf.amaassn.org/undefined/ documentDownload?uri=\%2Funstructured $\% 2$ Fbinary $\% 2$ Fletter $\% 2$ FLETTERS $\%$ 2F2018-3-27-Letter-to-Azar-re-Response-to-Proposed-Rule.pdf.

The regulation brings to mind the situation in Mississippi, where "[a] health care provider has the right not to participate, and no health care provider shall be required to participate in a health care service that violates his or her conscience." Miss Code Ann. 41-107-5 (2013). A health care provider is "any individual who may be asked to participate in any way in a health care service, including but not limited to: a physician, physician's assistant, nurse, nurses' aide, medical assistant, hospital employee, clinic employee, nursing home employee, pharmacist, pharmacy employee, researcher, medical or nursing school faculty, student or employee, counselor, social worker or any professional, paraprofessional, or any other person who furnishes, or assists in the furnishing of, a health care procedure." Miss Code Ann. 41-107-3(b) (2013). A health care service is "any phase of patient medical care, treatment or procedure, including, but not limited to, the following: patient referral, counseling, therapy, testing, diagnosis or prognosis, research, instruction, prescribing, dispensing or administering any device, drug, or medication, surgery, or any other care or treatment rendered by health care providers or health care institutions. Miss. Code Ann. § 107-3(a) (emphasis added). Although a health care provider may not "refuse to participate in a health care service regarding a patient because of the patient's race, color, national origin, ethnicity, sex, religion, creed or sexual orientation," recall the same population's assertion that "sex" does not include "gender identity." See discussion infra Part II Section B. 
discrimination against the transgender population, while the breadth of the final rule protecting health care providers' conscience objections affirmatively authorizes a wide range of discrimination against people who are transgender. Combined, the message to the transgender population is that transgender individuals are not welcome, resulting in both psychological and physical health care disparities. The result is a "public health crisis." 53

The Administration's regulatory actions leave the transgender community with nowhere to turn if experiencing difficulty obtaining mental or physical health care services. Interpreting section 1557 as omitting "gender identity" from the list of prohibited grounds for discrimination in health care means there is not an explicit source of civil rights protection for that population. Should an institutional health care provider decide to serve the community, individuals or associated entities within that health care provider can refuse "to perform" and "to assist in performance of" all types of services-not particular, specified services-if asserting a sincerely held religious belief or moral conviction that the transgender existence is unacceptable. The combination of these regulatory actions signal that the Trump Administration has given its seal of approval to refusals to care for the transgender population.

\section{A. Eliminating a Source of Legal Protection in the Section 1557 Regulations}

Even considered separately, the regulations at issue have the potential to both psychologically and physically harm members of the transgender community. Re-defining "gender" to eliminate the prohibition of discrimination against transgender persons transforms trans individuals into the modern-day equivalent of the Little Rock Nine, enduring "daily indignities, threats and violence" when showing up for medical care, just as those nine African-American students did when they showed up to go to a white school in 1950s Little Rock, Alabama.54 Medically, "the proposed HHS definition of gender [in the section 1557 regulations] would ignore the unique physical and mental

53 Wilson, supra note 19 , at 612.

54 Lina Mai, 'I Had a Right to be at Central': Remembering Little Rock's Integration Battle, TIME (Sept. 22, 2017), http://time.com/4948704/little-rocknine-anniversary/. 
health needs of 1.4 million adults and 150,000 adolescents who identify as [transgender and gender diverse]." 55

Governmental support of discrimination will place additional barriers in the way of transgender individuals attempting to access health care services. Even Cheyn Onarecker, chair of the healthcare ethics council at Trinity International University's Center for Bioethics and Human Dignity, acknowledges that "if a physician refuses to provide certain healthcare services, it makes it more difficult for patients to obtain access to those services." ${ }_{6} 6$ Without access to care, neither physical nor mental health can improve; they may not even remain static, but instead may worsen. As Professor Wilson has recognized, individuals experiencing gender dysphoria, for example, have higher rates of depression, anxiety, and suicide than the general population. ${ }^{57}$

The mere presence of laws permitting discrimination also can result in increased mental distress.58 A recent study involving 109,089 participants in nine states demonstrated that merely having state laws permitting denial of services on the books in their states resulted in a forty-six percent increase in sexual minority adults experiencing mental distress. ${ }^{59}$ Individuals were considered "sexual minorities" if they self-identified as "gay, lesbian, bisexual, or not sure of their sexual orientation."60 The researchers studied adults aged eighteen to sixty-four years in three states that passed laws permitting denial of services to same-sex couples: Utah, Michigan, and North Carolina. ${ }^{61}$ The

55 Kelly McBride Folkers et al., Redefining Gender Would Have Serious Physical and Mental Health Consequences, Health AFF. Blog (Nov. 27, 2018), h ttp://www.healthaffairs.org/do/10.1377/hblog20181120.814387/full/?utm_campa ign=HASU\&utm_medium $=$ email\&utm_content=Administration+Targe. See also Laura L. Kimberly et al., Ethical Issues in Gender-Affirming Care for Youth, 142 PEDIATRICs 1 (2019).

56 Debate Over Whether 'Conscience Rule' Engenders Diversity or Paternalism, RELIAS MEDIA (June 18, 2019), http://www.reliasmedia.com/articles /144615-debate-over-whether-conscience-rule-engenders-diversity-or-paternalis $\mathrm{m}$.

57 Wilson, supra note 1 , at 602.

58 See Julia Raifman et al., Association of State Laws Permitting Denial of Services to Same-Sex Couples with Mental Distress in Sexual Minority Adults, 75 JAMA PsYCHIATRY 671 (2018).

59 Id. at 674.

$60 \mathrm{Id}$. at 672 .

61 Id. (Utah allowed government officials to refuse to "participate in issuing marriage licenses for same-sex couples." Michigan passed a law permitting "adoption and child welfare agencies to refuse to permit same-sex couples to adopt children." North Carolina passed two laws-one "allowing magistrates to 
researchers' goal was to "evaluate whether the implementation of laws permitting denial of services to same-sex couples was associated with changes in mental distress among sexual minority adults."62 It concluded that "laws permitting denial of services to sexual minorities... are associated with a [forty-six percent] increase in the proportion of sexual minority adults experiencing mental distress."63

In other words, state laws permitting denials of services already contribute to the incidence of mental distress among sexual minorities. ${ }^{64}$ Members of the transgender community already are vulnerable and under-served in terms of mental health care. "Being refused a treatment because of... identifying as a member of a group can be harmful to a person's psychological and social sense of health and wellbeing."65 Transgender individuals "experience enormous psychological distress across their lives."66 Yet, rather than attempting to deal with that distress, the proposed revision of the section 1557 regulation is likely to deepen it.

The political logjam over respect for the transgender community in health care has inspired many discussions about nature versus nurture, or predilection versus choice. ${ }^{67}$ But as Professor Wilson states, regardless of causation of "transgenderism," the physical and mental distresses, partly caused by external prejudice and discrimination, plague the transgender community, resulting in a "very real public health crisis facing this community."68 The Administration's position propels the United States further out of step with the rest of the world; the proposed definition of "gender" as being determined by the physical characteristics with which one is born runs directly counter to what a group of authors from the World Health Organization have termed a "growing commitment in public health to understand and improve the health and well-being of

refuse to perform same-sex marriages" and one "prohibiting cities or counties from passing laws preventing discrimination based on sexual orientation or gender identity.").

62 Id. at 674.

$63 \mathrm{Id}$. at 675.

64 See id. at 671-677.

65 Klugman, supra note 4.

66 Wilson, supra note 1, at 586.

67 See Robin F. Wilson, Common Ground in Lawmaking: Lessons for Peaceful Coexistence from Masterpiece Cakeshop and the Utah Compromise, 51 ConN. L. REV. 1 (2019).

68 Wilson, supra note 1 , at 587. 
2020]TODAY'S CRUSADES: A THERAPEUTIC JURISPRUDENTIAL CRITIQUE OF FAITH-BASED CIVIL RIGHTS IN HEALTH CARE

transgender people and other gender minorities."69

\section{B. Elevating Providers Above Patients in the Conscience Clause Regulations}

The conscience clause regulations are no better; indeed, they may be worse. Before the most recent regulatory activity, a rule promulgated in $2011^{70}$ governed conscientious objection to participation in abortion and sterilization procedures under the Church Amendments; ${ }^{71}$ section 245 of the Public Health Services Act, codified at 42 U.S.C. $§ 238 \mathrm{n} ;{ }^{72}$ and the Weldon Amendment. ${ }^{73}$ In that rule, HHS explained that the rule's applicability to only these three statutes did not invalidate other conscience clause protections embedded with various federal statutes. It informed health care providers that they had to "continue to comply with the long-established requirements of [those] statutes" and described those statutes as "strik[ing] a careful balance between the rights of patients to access needed health care, and the conscience rights of health care providers." 74

Such statements apparently did not quell the concerns of commenters who had objected to the 2011 regulation; they wanted more protection lest they "be required to perform procedures that violate their religious or moral convictions." 75 In response to individuals and corporate entities continuing to voice their concerns years later, President Trump in May 2017 issued an executive order signaling a more proactive stance than previous administrations had exhibited by describing "the policy of the executive branch" as being "to vigorously enforce Federal law's robust protections for religious freedom." 76 Almost five months later, the Department of Justice issued a memorandum

\footnotetext{
69 Thomas et al., supra note 19 , at 154 .

7045 C.F.R. pt. 88 (2019); Regulation for the Enforcement of Federal Health Care Provider Conscience Protection Laws, 76 Fed. Reg. 9968, 9968 (proposed on Feb. 23, 2011) (codified at 45 C.F.R. pt. 88). For a recap of the history of federal conscience clause regulations, see Keith, supra note 47.

7142 U.S.C. § 300a-7 (2009).

7242 U.S.C. $\S 238$ n (2012).

73 Consolidated Appropriations Act of 2009, Pub. L. No. 111-117, 123 Stat. 3034.

74 Regulation for the Enforcement of Federal Health Care Provider Conscience Protection Laws, 76 Fed. Reg. at 9973.

75 Regulation for the Enforcement of Federal Health Care Provider Conscience Protection Laws, 76 Fed. Reg. at 9971.

76 Exec. Order No. 13798 § 1, 82 Fed. Reg. 21,675 (May 4, 2017).
} 
providing guidance to federal departments and urging all federal departments, including HHS, "to implement and enforce all relevant religious freedom laws." 77 Consistent with that theme, in January 2018, HHS created a Conscience and Religious Freedom Division within its Office of Civil Rights (OCR) "to enforce the rights of doctors, nurses and others who invoked such objections."78

Concurrently, the OCR published a "proposed regulation broadening the scope of enforcement of 'provider conscience' laws."79 The proposed regulation addressed in detail each of ten categories of conscience clauses in federal law. ${ }^{80}$ It thus significantly expanded upon the earlier regulation with respect to these statutes, stating that the final rule "revise[s] [the earlier rule] from a minimal regulatory scheme to one comparable to the regulatory schemes implementing other civil rights laws." 81

In May 2019, after a comment period, HHS issued final regulations. ${ }^{82}$ In the final version, most provisions, like most of the statutes, deal with concerns about being or feeling forced to participate in abortions, sterilizations, and other reproductionrelated procedures. ${ }^{83}$ A tiny fraction address religious or moral objections to withholding or withdrawing life-sustaining treatment, medical aid in dying, and euthanasia (although

77 See Office of the Att'y Gen., Memorandum for All Executive Departments and Agencies, Federal Law Protections for ReLigious Liberty (Oct. 6, 2017); U.S. DeP't of Health \& Hum. Servs, HHS Announces Final Conscience Rule Protecting Health Care Entities and Individuals (May 2, 2019), http://www.hhs.gov/about/news/2019/05/02/hhs-announces-final-conscienc e-rule-protecting-health-care-entities-and-individuals.html.

78 Brendan Pierson et al., Trump Move on Health Care Religious Freedom Prompts Discrimination Fears, 32 WESTLAW J. EMP. 11, 11 (2018).

79 Naomi Seiler \& Katie Horton, The Bioethical and Legal Implications of HHS's New Focus on Conscience and Religious Freedom, 18 AM. J. BIOETHICs 71, 71 (2018).

80 Protecting Statutory Conscience Rights in Health Care; Delegations of Authority, 83 Fed. Reg. 3,880, 3,880 (proposed Jan. 26, 2018) (to be codified at 45 C.F.R. pt. 88). See also Keith, supra note 47. (describing the final rule as "expand[ing] and consolidat[ing] OCR's enforcement authority over a total of 25 federal health care conscience laws, including three parts of the Affordable Care Act").

81 Protecting Statutory Conscience Rights in Health Care; Delegations of Authority, 84 Fed. Reg. 23,170, 23,229 (proposed May 21, 2018) (to be codified at 45 C.F.R. pt. 88) (emphasis added).

82 U.S. DeP'T OF Health \& Hum. Servs, supra note 75.

83 Protecting Statutory Conscience Rights in Health Care; Delegations of Authority, 84 Fed. Reg. at 23,265-66. 
euthanasia is illegal in every state in the union in any event). ${ }^{84}$ Some, however, based on the few broader federal statutory provisions, set forth extremely broad regulatory definitions. ${ }^{85}$

The objective of the recently finalized regulations, according to HHS, is "to protect the conscience and associated antidiscrimination rights of individuals, entities, and health care entities." 86 HHS advises that both the statutes upon which the regulations are based and the regulations themselves "are to be interpreted and implemented broadly to effectuate their protective purposes." 87 Several times throughout its explanation of the final rule, HHS refers to the statutory provisions giving it the power to promulgate these regulations as civil rights statutes meriting broad construction. ${ }^{88}$ Consistent with its civil rights theme, HHS now refers to the statutory provisions traditionally known as conscience clauses as "conscience and antidiscrimination laws." 89

Overall, HHS has described the final rule as "fulfill[ing] President Trump's promise to promote and protect the fundamental and unalienable rights of conscience and religious liberty" in his executive order and added that it "shares the anticipation of many commenters who reasoned that the rule will promote a culture of respect for rights of conscience and religious freedom in health care that is currently lacking." 90

These regulations represent another aspect of the same concerns expressed more narrowly with respect to the proposed regulations relating to section 1557. Of merit without question are conscientious objections to certain procedures in certain circumstances, as long as the moral or religious objections are legitimate and sincerely held. ${ }^{91}$ As the 2011 rule's comments

84 Protecting Statutory Conscience Rights in Health Care; Delegations of Authority, 84 Fed. Reg. at 23,267.

85 Protecting Statutory Conscience Rights in Health Care; Delegations of Authority, 84 Fed. Reg. at 23,204-05, 23,208, 23,212, 23,217, 23,223, 23,231; id. at 23,246 (listing estimated benefits from this regulation). See also supra Section II.B.

86 Protecting Statutory Conscience Rights in Health Care; Delegations of Authority, 45 C.F.R. $\S 88.1$ (2019).

8745 C.F.R. $\S 88.1$.

88 Protecting Statutory Conscience Rights in Health Care; Delegations of Authority, 84 Fed. Reg. at 23,174, 23,184.

8945 C.F.R. $\S 88.9$.

90 Protecting Statutory Conscience Rights in Health Care; Delegations of Authority, 84 Fed. Reg. at 23,230.

91 See supra Section II.B. 
stated,

The Federal provider conscience statutes were intended to protect health care providers from being forced to participate in medical procedures that violated their moral and religious beliefs. They were never intended to allow providers to refuse to provide medical care to an individual because the individual engaged in behavior the health care provider found objectionable. ${ }^{92}$

The new conscience clause regulations go far beyond the intent of the 2011 rule and far beyond what medical ethics instructs. They permit religious or moral objections not only to procedures, but also to certain people. ${ }^{93}$ They improperly permit physicians and other health care professionals to leave patients requiring care high and dry, without referrals or information about the treatment they seek. ${ }^{94}$ At a minimum, they "topple" the "delicate balance" between patient and professional rights. ${ }^{95}$

\section{The NeED to InCORPoRATE PRINCIPLES OF MEDICAL ETHICS INTO THE REGULATIONS}

The beauty of therapeutic jurisprudence (TJ) as a foundation for analysis and improvement of laws and procedures is its interdisciplinary nature. ${ }^{96}$ Interdisciplinarity is necessary; with respect to laws governing access to health care for a vulnerable population, the best policies will result only after full

92 Regulation for the Enforcement of Federal Health Care Provider Conscience Protection Laws, 76 Fed. Reg. 9,968, 9,973-74 (proposed Feb. 23, 2011) (to be codified at 45 C.F.R. pt. 88).

93 See Mark Wicclair, Conscience Clauses: Too Much Protection for Providers, Too Little for Patients, 18 AM. J. Bioethics 53, 55 (2017) (writing before the rule was finalized, but with respect to a feature that was not modified between proposal and finalization, stating that "[t]he proposed rule overlooks... whether refusals are based on moral or religious beliefs that endorse invidious discrimination").

94 See Curlin et al., supra note 33. "Most of the physicians in [one] survey reported that when a patient requests a legal medical intervention to which the physician objects for religious or moral reason, it is ethically permissible for the physician to describe the reason for the objection but that the physician must also disclose information about the intervention and refer the patient to someone who will provide it." Id.

95 See Sepper, supra note 37.

96 David B. Wexler, The DNA of Therapeutic Jurisprudence, in THE Methodology And Practice of Therapeutic Jurisprudence 6 (2019) (cofounder of therapeutic jurisprudence writing of the "obvious... interdisciplinary nature of TJ and its development"). 
consideration of not only providers' preferences but also psychological and physical risks for patients, medical ethical opinions, and the potential for improving the health care system. ${ }^{97}$ TJ counsels us to consult those disciplines, consider the law's therapeutic or anti-therapeutic effects on those it affects, and, importantly, see if the other disciplines have solutions to offer to remedy any anti-therapeutic effects of the law. 98

In this case, other disciplines have a great deal to offer. Ignoring for the time being legal arguments others are raising about the administrative interpretations of the law in these regulations, ${ }^{99}$ basic principles of medical professionalism and ethics illustrate their flaws. Considering the important antitherapeutic effects of the Administration's positions with regard to health care access for transgender individuals leads to two inescapable conclusions: DOJ must include "gender identity" in the regulations interpreting section 1557, and HHS must interpret the conscience clause regulations (or, better yet, revise them) at least to require referrals rather than permit refusals to provide referrals.

Professor David Yamada has written that the Trump Administration's efforts to reform immigration and health care policy illustrate "how [the] law can operate in a profoundly antitherapeutic manner, replete with fear and trauma experienced by the most vulnerable among us, thus constituting severe denials of human dignity." 100 The same is true of these regulations. At their core, the regulatory changes addressed in this article rob many persons - including but most assuredly not limited to those of non-binary gender identity - of human dignity by permitting

97 Cerminara, supra note 11.

98 See Nigel Stobbs, How to do Therapeutic Jurisprudence Research, InT'L SOC'Y FOR THERAPEUTIC JURIS (May 20, 2015), http://mainstreamtj.wordpress.co $\mathrm{m} / 2015 / 05 / 20 /$ how-to-do-therapeutic-jurisprudence-research/ (explaining that TJ "has always had a strong focus on applying and adapting knowledge from other disciplines (especially the social and health sciences)").

99 See, e.g., Elissa Gershon, Response to Proposed Rule Changes of Section 1557, the Nondiscrimination Provision of the Affordable Care Act (ACA), DisABILITY RTS. CAL. (Aug. 13, 2019), http://www.disabilityrightsca.org/post/res ponse-to-proposed-rule-changes-of-section-1557-the-nondiscrimination-provision -of-the.

100 David C. Yamada, On Anger, Shock, Fear, and Trauma: Therapeutic Jurisprudence as a Response to Dignity Denials in Public Policy, 63 InT'L J.L. \& PSYCHIATRY 35, 36 (2018) (with respect to health care policy, using attempts to repeal protection of persons with health insurance because of the ACA from once-permitted discrimination based on pre-existing conditions). 
others to turn them away at the door because of who they are..$^{101}$ But "[a]bandoning patients or refusing to treat populations of patients are not approaches to medical practice that ethicists can support."102

With respect to section 1557 , the regulatory process is still ongoing. Thus, the DOJ still has an opportunity to act therapeutically by re-inserting "gender identity" into its regulation. Doing so would help combat the mental and physical individual and public health crisis existing among the transgender community.

The conscience clause regulations, which already have proceeded through the notice-and-comment process, pose a trickier problem. Litigation proceeds with respect to their validity, but in the meantime, the best way to promote a therapeutic health care system is for medical ethicists to "educat[e] clinicians about the duties of care they owe to all patients without discrimination." 103 Respect for rights of conscience and religious freedom do not require privileging health care providers over patients, as these regulations do. ${ }^{104}$ To the contrary, medical ethics would forbid privileging health care providers over patients. ${ }^{105}$

The American Medical Association, for example, protested the breadth of the proposed conscience clause rule during the comment period, explaining:

[W] hile we support the legitimate conscience rights of individual health care professionals, the exercise of these rights must be balanced against the fundamental obligations of the medical profession and physicians' [and medical students' and residents'] paramount responsibility and commitment to serving the needs of their patients. As advocates for our patients, we strongly support

101 The phrase "because of who they are" is likely to engender a debate over causation, as noted earlier in section II.A, but regardless of causation of "transgenderism," the physical and mental state of the transgender community signifies a "very real public health crisis facing this community." Wilson, supra note 1 , at $586-87$.

102 ReLias MeDia, supra note 56 (emphasis added).

103 Id.

104 Protecting Statutory Conscience Rights in Health Care; Delegations of Authority, 84 Fed. Reg. 23,170, 23,182 (May 21, 2018) (to be codified at 45 C.F.R. pt. 88) (rejecting comments arguing that the regulations "place[d] health care providers above patients").

105 Physician Exercise of Conscience: Code of Medical Ethics Opinion 1.1.7, supra note 34 . 
patients' access to comprehensive reproductive health care and freedom of communication between physicians and their patients, and oppose government interference in the practice of medicine or the use of health care funding mechanisms to deny established and accepted medical care to any segment of the population. ${ }^{106}$

The AMA expressed concern that permitting "individuals and health care entities who receive federal funding to refuse to provide any part of a health service or program based on religious beliefs or moral convictions, will allow discrimination against patients, exacerbate health inequities, and undermine patients' access to care." 107

Considering itself to be regulating within a civil rights paradigm, HHS responded to comments by saying, "[c]onscience protections should be not be [sic] a special exception to the principle that fundamental rights do not depend on there being zero conflicts or disagreements in their exercise." 108 It refused to balance providers' rights against the deep psychological harm to individuals that can result from the type of stigma endured by those turned away at a health care provider's door. ${ }^{109}$ Congress itself may not have "establish[ed] balancing tests that weigh such emotional distress against the right to abide by one's conscience," 110 but, as bioethicist Craig Klugman states, this "rule violates providers' most important duties: [t]o do no harm, and to put patients' needs above one's own."111

Until the courts step in or another administration revises the regulations to return to the appropriate regulatory balance, health care entities and individuals asserting conscience objections must, at a minimum, learn that HHS is relying on their observance of their ethical duties despite the text of the overbroad regulation. Comments on the proposed regulations had expressed concern that explicit protection of refusals to refer "would interfere with legal and ethical duties of doctors to

106 Letter from James L. Madara, Exec. Vice President, CEO, American Medical Association, supra note 52 (emphasis added).

107 Id. (emphasis added).

108 Protecting Statutory Conscience Rights in Health Care; Delegations of Authority 84 Fed. Reg. at 23,251.

109 Protecting Statutory Conscience Rights in Health Care; Delegations of Authority 84 Fed. Reg. at 23,251 (listing the harms considered).

110 Protecting Statutory Conscience Rights in Health Care; Delegations of Authority, 84 Fed. Reg. at 23,251.

111 RELIAS MEDIA, supra note 56. 
provide information to their patients," but HHS disagreed. ${ }^{112}$ It responded:

The rules do not prohibit any doctor or health care entity from providing information to their patients-or referring for a medical service or treatment-if they feel they have a medical, legal, ethical, or other duty to do so. The rules simply enforce existing laws that prevent doctors or other protected entities from being forced to refer for abortions against their will or judgment. The rule's definition of "referral or refer for" ensures that doctors can use their own professional, medical, and ethical judgment without being coerced by entities receiving Federal funds to violate their moral or religious convictions. ${ }^{113}$

The new regulations, however, lack the ethically supportive force of the 2011 regulations. They fail to affirmatively assure individuals that they can trust their health care providers by signaling that providers were intended to balance "the rights of patients to access needed health care, and the conscience rights of health care providers." 114 They eliminate the law's previous trust-supportive stance, thus eliminating what one might characterize as a "deliberate and calculated attempt either directly to foster the psychology of trust or more indirectly to create conditions that are conducive to trust." 115 They do this with respect to a population already experiencing health care providers' rejection more often than we may think. ${ }^{116}$ Although

112 Protecting Statutory Conscience Rights in Health Care; Delegations of Authority, 84 Fed. Reg. at 23,200 (rejecting comments arguing that the regulations "would interfere with legal and ethical duties of doctors to provide information to their patients").

113 Protecting Statutory Conscience Rights in Health Care; Delegations of Authority, 84 Fed. Reg. at 23,200.

114 Regulation for the Enforcement of Federal Health Care Provider Conscience Protection Laws, 76 Fed. Reg. 9,968, 9,973 (proposed Feb. 23, 2011) (codified at 45 C.F.R. pt. 88). The trust affirmed is trust that providers will act ethically. According to law professor and ethicist Larry Gostin, "[e]thicists need to fairly balance the rights of providers who have genuine conscience reasons for withholding care with the rights of patients to high-quality treatment for all conditions." RELIAS MEDIA, supra note 56.

115 Mark A. Hall et al., Law, Medicine, and Trust, 55 STAN. L. REV. 463, 498 (2002) (identifying trust between patients and providers as an important facet of medical care and characterizing type of laws related to trust within the field).

116 See Shabab Ahmed Mirza \& Caitlin Rooney, supra note 39; Keren Landman, supra note 39 ("These findings are similar to those in the 2015 US Transgender Survey, in which 23 percent of respondents reported abstaining from necessary healthcare over the past year due to fear of being mistreated by 
HHS notes that it "is not aware of any providers that would refuse to treat or refer a person with unforeseen and unintended complications arising from, for example, an abortion procedure that the provider would not perform," empirical research has indicated that a sizable number of physicians "do not believe they are [ethically] obligated to disclose information about medically available treatments they consider objectionable" or "to refer the patient to another provider for such treatments." 117 Education is required.

HHS expects its conscience clause rule to "decrease the harm that providers suffer when they are forced to violate their consciences, with attending improvements to patient health" 118 and reduce the incidence of "harm that being forced to violate one's conscience inflicts on providers." 119 Stating that "Congress likely intended to protect objecting providers" by passing the statutes this rule interpreted, ${ }^{120}$ it notably does not deny that harm could result to some people as a result of the breadth of its rule. Instead, HHS chides commenters for failing to provide empirical evidence to that effect. In light of this sub silentio agreement that harm could arise from improvident refusals to treat based on religion or morals, HHS should understand that requiring referrals for practices to which physicians object on religious or moral bases is "only reasonable." 121

\section{CONCLUSION}

"[I]t is time for us to be unapologetically and responsibly bold in advocating for laws, legal systems, and legal institutions that advance a more humane society." 122 The Trump

providers.").

117 Protecting Statutory Conscience Rights in Health Care; Delegations of Authority, 84 Fed. Reg. at 23,201; Curlin et al., supra note 33, at 597.

118 Protecting Statutory Conscience Rights in Health Care; Delegations of Authority, 84 Fed. Reg. at 23,246. See also Protecting Statutory Conscience Rights in Health Care; Delegations of Authority, 84 Fed. Reg. at 23,247.

119 Protecting Statutory Conscience Rights in Health Care; Delegations of Authority, 84 Fed. Reg. at 23,248.

120 Protecting Statutory Conscience Rights in Health Care; Delegations of Authority, 84 Fed. Reg. at 23,248.

121 Christian Medical and Dental Society of Canada v. College of Physicians and Surgeons of Canada, 2019 ONCA 393, para.187 (Can. Ont. C.A.) (stating that a patient's interest in receiving clinically appropriate services or formal referrals for such should prevail over physicians' moral conflicts).

122 Yamada, supra note 100, at 39. 
Administration's Crusades against the transgender population have moved from rhetoric to support of actions that will result in additional mental and physical health problems for that population. There is still time for HHS to correct the wrong it proposes in the regulation interpreting section 1557 by reinstating the language echoing judicial decisions interpreting "gender" as including "sex stereotyping, pregnancy (and termination of pregnancy), and gender identity,"123 in the regulatory definition of gender. As for the now-completed conscience clause process, it is possible to advocate and hope for judicial correction or administrative reconsideration. In the meantime, however, provider education is required so that those the conscience clause regulations protect recognize their ethical duties to balance their rights against those of patients or prospective patients.

123 Sepper \& Roberts, supra note 24, at 219; Nondiscrimination in Health Programs and Activities, 81 Fed. Reg. 31,375, 31,387 (proposed on May 18, 2016) (to be codified at 45 C.F.R. pt. 92). 